\title{
To Unveil an lota of the Muslim Cultural Mask
}

\section{Zhengshun Han}

Wuhan Textile University, Hubei Province, Wuhan,China.430073

hanzhengshun@126.com

\begin{abstract}
Keywords: identity, propriety, prejudice, evil eye
\end{abstract}
\begin{abstract}
Mohamed Moulessehoul, a world famous Algerian writer,adopts as his pen name his wife's Yasmina Khadra to publish all his bestsellers in French out of reasons for his appreciation for and awe of her, but also for avoiding political censorship in Algeria.Among his most-noted works include his trilogy The Swallows of Kabul, The Attack and The Sirens of Bagdad . In 2004, Newsweek honors him as a rare literary writer who gives meaning to hardships. His works are rendered into more than forty languages across the world. In addition, his work What the Day Owes the Night was made into movie with the same title,which turn out to be a hit worldwide. It relates the story of a landless farmer's son named Younes, a handsome blue-eyed young Arab, and his dear French girlfriend Emilie.They loved each other from their childhood but were unable to marry till death do them apart.This present thesis attempts to delineate the cultural messages decoded in the book: that is, over the matters of identity; propriety; prejudice and the evil eye, so as to uncover the art value and exotic beauty from the peculiar perspective of cross-cultural communication.
\end{abstract}

\section{Introduction}

The French movie entitled What the Day Owes the Night was very highly acclaimed over the internet since it release in 2012. For instance,(1)Huan Chen's review titled "An Uncandid Algerian Epic" thinks that the French was uncandid in shooting the movie concerning Algerian history for being specious and not brave enough to show limitless courage, only feeling shameful of it and then can they become brave.[1].(2)Z Kabutengni's essay entitled "A Lifetime Brim with True Love as Well as Regret and Remorse"maintains that the narrator, as a youngster, could not take complete control of himself, and succumbs to temptation. Later on, he was unable to be courageous enough to face his true love. He kept his promise but paid a huge lifetime price though well qualified for it before his God [2]. (3)feelin's paper named "What the Day Owes the Night:A Mediocre French Beauty"considers Emilie's mother, who had no sense of belongings to Algeria, to be a certain sort of metaphor for the contradictions between France and Algeria. The mediocrity of the movie also lies in the depiction of the historical background with the colonists being noble and beautiful and sentimental while the colonized remain dirty, miserable, violent and bloody, which is generally deemed as inconsequential amid the aura of limitless tender feelings when taken this movie as a whole.[3] Above all, the grand and glorious youth period passes swiftly. Golden Age is the time when you filter through all the life's dirt and polished its spectrum of light,the spectacular charm of which is like a poetry, or a painting or a blossom, making you feel like being at the time and place of Algeria.

\section{The Matter of Specious, Flickering and Somewhat French-Algerian Identities}

First of all, speaking in terms of cross-cultural communication,"Diversity is rich". Nevertheless, in the Colonial Period, the colonists and the colonized are in a state of being master and servant. These identities predominate all things. By identity, we mean an abstract, complicated, and dynamic concept. It means that" a person's conception of self within a particular social, geographical, cultural, and political context.---Identity gives the individual a sense of self and personhood."[4]. We tend to see it as "a person's self-definition as a separate and distinct individual, including behaviors, beliefs, and attitudes."[5]. It is of paramount importance to the psychic well-being and sense of value of an individual. Otherwise, it will create chaos in identities, awkwardness, and even violence and sometimes riots. In this novel, first thing first, the identity issue lies in the marriage of his uncle who was an Arab while his aunt was a French. They got engaged in college, married after graduation 
defying all obstacles that came along. This inter-racial marriage ended up in a perfect union with the only exception of having no child. When the riots arose between Arabs and French, his uncle was spotted for his political position which drove his aunt mad and transformed his uncle irrevocably.Subsequently, they were forced to move from Jenane Jato to the small town of Rio Salado and continue to do their business of pharmacy.Secondly, the narrator had to live with his uncle out of no way- out, which yields the identity issue: his name was changed from Younes to Jonas which sounded like French to hide his identity. Later on, he met the French girl of Isabella. When she realized that he was an Arab,she stopped to be his companion which scarred his little heart for ever.Thirdly,when Emilie strongly proposed to him, she just screamed out:"Is it because I'm a Christian and you are a Muslim?" "No."[6] Although he really loved her but being unable to say it thanks to his promise with her mother---Madame Cazenave--- of not even approaching her daughter for the sake of incision. Fourthly, Madame Cazenave, whose husband is said to have gone to Amazon Forest and eloped with a sexy big-hipped native there, lived near the pharmacy of Younes on a small hill. She tempted Younes and seduced him under the pretext of asking him to send her some medicine.Then she simply denied their affair and demanded that he never approach her daughter.This interlude makes Younes misjudge his identity and so he mistakes Madame for his own destiny:"For one searing instant, I mistook her for my destiny."'[7].Overall, the issue of identity always perplexed and puzzled him very much for he looked like a French thanks to his blue eyes and handsome face but he was indeed an Arab. It also affects people around him immensely. He felt swayed and wedged between two identities.Just as what he once remarked: "I should have come here regularly to fill the gaps in my identity. Rio Salado and I no longer spoke the same language; how should I speak now? When I lived in Rio Salado, had I been Jonas or Younes? Why?" [8] This is the telling embodiment of his torn mentality and confusion of his identities.

\section{The Matter of Small but Sensitive, Delicate but Sometimes Unspeakable Propriety}

To Muslims, appropriate speech and manners remain paramount and supreme.Based on their belief, the word "Muslim" itself means"submission"to the will of God. Their only God of Allah or Muhammad has 99 beautiful names,99 virtues,and 99 beads. Piety,simplicity,passion and belief constitute the main sources of power for all followers.In the gap between God of the Qur'an and humankind, there exists the hierarchy of angels with Gabriel---the arch-angel--- being of the highest rank, then succeeded by the rest of the angels. This belief holds that each person has two angels assigned to him or her: one to record the person's good deeds, and then the other to record the bad deeds.[9] It also posits that the adherents believe in the Day of Judgment. The God of the Qur'an has decreed that there will come a day when all stand before Him in judgment. On that particular day, each person's deeds will be weighed in the balance. Therefore, those whose good deeds outweigh their bad deeds will be rewarded with Paradise: and those whose bad deeds surpass their good will be judged to go to hell.[10].

The English essayist Joseph once observed:"Modesty is not only an ornament, but also a guard to virtue."[11] For instance, because of the cultural emphasis on modesty and female purity, Muslims are often very shy about disrobing for medical check-up. In this male-dominated culture, modesty is of paramount importance. Males are charged with protecting female honor, and females are expected to be virgins before their marriage. It is only their husband that can be allowed to see them naked. Once these rules are broken, it dishonors the family. Consequently, the only thing that honor can be restored to a family in which female purity and modesty have been compromised is to punish the girl, customarily stoned to death by villagers[12].

In this novel, first of all, the narrator briefly introduced some unwritten conventions and manners of Muslims:"In our world, when men meet, women are expected to withdraw; there is no greater sacrilege than to see one's wife stared at by a stranger. My mother did as she was asked."[13] This is somewhat like Chinese feudalist thought of "man is superior to woman".Even a shepherd, out of hospitality, voluntarily offered this homeless family to stay in his house, he was very alert:"Out of .modesty, he dare not come any closer while my mother was present."[14]. Besides , Bliss---the broker, a vulture who can't wait to grow rich on others' misery, often exhibited this behavior:"He 
asked us to wait in the street, then cleared his throat loudly to let the women know to disappear---as was the custom if a man was about to walk into a room. When the coast was clear, he signaled us to follow him."[15].No doubt,we can get a glimpse of the prescribed rules and regulations of this community. Right at the outset, when the father found that wheat---his fruit of hard labor---was burned to the ground overnight, the narrator cannot help exclaiming thus: "It was then that I realized that our guardian angels had abandoned us, that we would be cursed until the day of judgment."[16] His face exuded limitless sorrow and sadness. Secondly,crude language does not stand a slim chance in this culture, for example:"There was Badra, a hefty, strapping woman who loved to tell dirty stories. She was a breath of fresh air.Her crude language made my mother uncomfortable, but the other women love it." [17]. Badra was always very humorous and fond of telling her dirty jokes which other women enjoyed and loved very much but his mother find it awful and awkward. Consequently,"To protect me from Badra's vulgar tongue, my mother allowed me to play in the street."[18].The response of his mother toward Badra was :"My mother, sitting with them, slightly aloof,---took no part in their conversation---she would flush and choke on her tea with embarrassment."[19].In addition, when conversing, they observed some forbidden topics : "The subject was a taboo, and in spite of his wisdom, his liberal values, a sense of propriety prevented him from raising the subject with me.In our community, such things were traditionally only ever alluded to,---’[20].Thirdly, proper behavior matters a lot, like, (1).Yezza, often beaten black and blue by her husband, was courageous to face this ruthless fact and remained graceful and elegant:" Out of a sense of propriety, the other women pretended not to notice.Yezza was proud of her black eye, she endured her husband's cowardly attack with dignity."[21] (2). When his father earned some money and bought a gift for each, he didn't forget to hide it as a model of manners and behavior to show his refinement:"He was determined to celebrate his reconciliation with Lady Luck ---out of respect for our neighbors, who rarely had much to eat."[22] (3).Highly conscious of it being indecent and disgraceful, he stopped following a woman and turned around:"I followed this woman along the boulevard then, realising that what I was doing was somehow indecent, I turned back."'[23] (4).Face value also means most to them, such as:"Now that I had lost my face, I was looking for a place to hide".[24] (5).Even shabby houses are concerned with dignity and ornament, hence:"Some of these shacks, out of a sense of decency, were hidden behind screens of tall cacti---."[25] so on and so forth. But as an outsider, while reading this novel, we cannot help reflecting on our own behaviors and manners so as not to incur resentments, offense and suspicions on the part of the others for the reasons of being sensitive delicate and sometimes unspeakable.

\section{The Matter of Deep-rooted and Ever-present Racial Prejudice}

The French essayist Voltaire once remarked:“prejudices are what fools use for reason.”[26] Deeplyheld negative and antagonist feelings towards others can result in serious communication problems for prejudices are directed at a social group and its members.Its functions include these four factors: (1).ego-defensive; (2).utilitarian; (3).value-expressive;(4).knowledge.It mainly results from three sources: namely,(1).societal sources; (2).maintaining social identity; (3).scapegoating. In this novel,this expression can be found in the following manners: (1). When Younes encountered his uncle,due to different economic background, they held diverse views toward education.His uncle blurted out the general belief held by ordinary people:"I know--Arab boys aren't supposed to go to school. They are supposed to work in the fields, look after the livestock."[27] but his uncle thinks otherwise and sends him to school.(2). When an Arab student fails to hand in his homework on time, there occurs this dire situation:"Maurice yelled 'Because Arabs are lazy and shiftless, sir' .The whole class had erupted with laughter and this had set me brooding. "[28] .How awkward and embarrassing it is to the narrator!(3). His uncle tried his best to convince him that Arabs and Europeans hold distinct views toward time in his manner: 'No, Arabs are not lazy, but we take the time to live life to the full.'It is something Europeans don't understand. To them, time is money. To us, time has no price. We can be happy simply taking the time to share a glass of mint tea,whereas nothing in the world is enough to make them happy. That is the difference between us,son.'[29] (4).Isabelle,his second girl friend,lectured him straightly:"Liar"---."it makes all the difference!"---."You surely don't think I could 
marry an Arab? I'd rather die!'[30].As a small child, such glimpse into the adult world can indeed scar you for life,Younes brooded.(5). One of the European who hired Arabs for long was strongly prejudiced against Arabs: "Arabs are like dogs, you have to beat them to get them to behave."[31].Given Younes' presence, he corrected himself quickly,well some Arabs.---."Don't be ridiculous. I've been employing Arabs for generations, I know what they're like--- Vipers, the lot of them.And that vermin confessed. He's been found guilty and I will personally see to it that he goes to the guillotine".[32] (6). Younes cannot comprehend why a destitute Arab who likened himself to a dog:"Why do you call yourself a dog?---You are a dog or a jackal, and every dog seeks out a master.Andre can't survive without Jelloul." [33]." even a dog would not live like this."[34].Obviously, you can well see what the strong impact of holding prejudice against Arabs is in this novel.It is a psychic trauma and scar, hardly bearable to both sides. So prejudice is deep-rooted and ever-present in this work and the world as well.

\section{A Regional, Religious and Interesting Phenomena: the Evil Eye.}

According to a Mexican adage,"One's face is the mirror of one's soul." A Yiddish proverb also states that "The face tells the secret".In sizing up a person, eyes have always been a fairly fascinating topic in terms of face. Even the "evil eye" remains just more than an expression.In one study, Roberts concludes that 67 out of 186 cultures believe in the evil eye. Regarding the power of the evil eye(mal ojo) in Mexico and Puerto Rico, Zuniga observes : "Mal ojo is believed to be the result of excessive admiration and desire on the part of another. Mothers may isolate their children for fear of having one become victim of mal ojo."[35] This also applies to this novel, in the writer's opinion. In this work, the evil eye find its expression mainly in the following eight occasions to stave off the unwanted attention from others so as to protect privacy or innocence of the narrator or decency of the public eyes . Respectively they are:(1). "To boast about the harvest before it was gathered in was to tempt the evil eye. I knew he was bitterly regretting boasting of his success when not a grain had yet been harvested."[36] .This is indeed a disaster to this family,uprooting them and make the homeless. (2). "father chose a lone olive tree behind a small hill, safe from prying eyes, and began to lash the branches together to make a shelter for the night."[37].To protect their privacy, he doesn't expect unwanted attention from others which is why he acts like this. (3)."My father said nothing.I saw his lips move and knew he was silently reciting verses from the Qur'an to ward off the evil eye."[38].He recites passages from the script to shun away this inauspicious thing. (4). "I will work harder than any man has ever worked.I will face down the evil eye." [39]. In other words, he thinks that his unparalleled working efforts would scare away the ominous.(5)."My father, who until now had always kept his plans to himself so as not to tempt the evil eye, now told my mother every detail of his plans to find more work,---."[40] Here, his father 's drive and motivation rests only on his dream of building a castle in the air---his beautiful mansion with gardens and flowers and keeps telling them that he would be back on his own feet.(6). 'Please, don't say any more', my mother begged, spitting on the ground to ward off the evil eye. 'Say nothing, and let things take their course. The evil eye has no pity for blowhards.' [41] To get rid of things evil, his mother advised his father not to count the chickens before they are hatched. (7). 'My little barefoot prince'.he said.'Isn't he handsome? 'Stop that, you will draw the evil eye on him.--'[42] . This is when his aunt was just bathing him, they both find him cute and adorable but are mindful of the undesired things.(8)."We would see some squalid shack, crushed by the weight of poverty and the evil eye."[43]Even ugly houses would stab their eyes, and so on. With these in mind, we often think of the cases in our culture, we sometimes try our best to avoid meeting the eyes of someone evil, to avoid direct eye contact with it so as not to be hurt inside and humiliated. We learned hard to look at people this way on our own. Isn't this useful and beneficial in our daily life?

\section{Conclusion}

To conclude, What the Day Owes the Night is a deeply moving tragicomedy that offers us a microscope which can allow us to perceive and detail the ordinary life of the mysterious Muslim world despite its apparent robe and veil. The novel is indeed a marvelous must-read for any with a 
intercultural consciousness.It depicts us their beautiful dream of an ethnically harmonious heaven.It describes the epic historical evolution of Algeria over the range of almost 100 years. It ,above all , portrays the panorama of cultural dimension of Arabs in general, and Algerian Arabs in particular. Just as a Chinese authority on Dreams of Red Mansion once remarks that Chinese can do without the Great Wall, but Chinese cannot do without Dreams of Red Mansion,so anyone interested in Arabs must study the novel in question as a debut or beachhead to understand Muslims,particularly, over the matters of identity, propriety,prejudice, evil eye and the like. The true love between Younes or Jonas and Emilie transcends time, race, promise, faith, but cannot cross the terrible fear in their hearts. "Only after something is done do we truly realise it cannot be undone."[44]as the narrator laments his lifelong loss of desire for her loyal heart. From this,we perceive a world of human nature by reading it, especially given this dimension of the dire straits of the author wedged between the two worlds of being an Algerian or European; of being in past or present; of love or loyalty; and of finally, surrendering to fate or taking complete control of his own destiny. It is a real hard choice to make, don't you think so?

\section{References}

[1] Huan Chen.An Uncandid Algerian Epic. http://movie.mtime.com/180291/reviews/7596658.html.

[2] Z Kabutengni .A Lifetime Brim with True Love as Well as Regret and Remorse. https://movie.douban.com/review/8224273/.

[3] feeling.What the Day Owes the Night:A Mediocre French Beauty. http://i.mtime.com/176879/blog/7598937/.

[4] Larry A Samovar. Richard E. Porter. Communication Between Cultures.6th.ed. Beijing: Peking University Press. .2009.P.111.

[5] Larry A Samovar. Richard E. Porter. Communication Between Cultures.7th.ed. Beijing: Peking University Press. .2012.P.102

[6] Yasmina Khadra. Frank Wynne trans. What the Day Owes the Night. London: Vintage .p.247.2011. [7].p163. [8].p265.

[9] Dean Halverson.The Illustrated Guide to World Religions.Singapore:Bethany House.p108.2003. [10].pp108-109.

[11]Larry A Samovar. Richard E. Porter. Communication Between Cultures.5th.ed. Beijing: Peking University Press. p.269.2004. [12].pp269-270.

[13] Yasmina Khadra. Frank Wynne trans. What the Day Owes the Night. London:Vintage .p.11.2011. [14].p14. [15].p21. [16].p9. [17].p27. [18].p29. [19].p37. [20].p248.[21].p37. [22].p57. [23].p298. [24].p266. [25].p108.

[26]Larry A Samovar. Richard E. Porter. Communication Between Cultures.6th.ed.Beijing: Peking University Press. .2009.P.323.

[27] Yasmina Khadra. Frank Wynne trans. What the Day Owes the Night. London:Vintage .p.34.2011. [28].p84. [29].p85. [30].p118. [31].p135. [32].p282. [33].p175. [34].p177.

[35]Larry A Samovar. Richard E. Porter. Communication Between Cultures.6th.ed.Beijing: Peking University Press. 2009.P.210.

[36] Yasmina Khadra. Frank Wynne trans. What the Day Owes the Night. London:Vintage .p.7.2011. [37].p14. [38].p18. [39].p35. [40].p49. [41].p57. [42].p65. [43].p108. [44].p262. 